\title{
SDHC Gene Mutation
}

National Cancer Institute

\section{Source}

National Cancer Institute. SDHC Gene Mutation. NCI Thesaurus. Code C48303.

A change in the nucleotide sequence of the SDHC gene. 